Received: 26/07/2019

Revision: 24/04/2020

Accepted: $16 / 05 / 2020$

OnlineFirst:06/08/2020

\title{
The Interplay of Self-Efficacy Sources and Reading Self-Efficacy Beliefs in Metacognitive Reading Strategies
}

\author{
Muhammad Waleed Shehzad \\ Asst. Prof., corresponding author, English Department, Foundation University \\ Islamabad (FUI), Islamabad, Pakistan,waleed.shehzad@fui.edu.pk
}

Tahira Anwar Lashari

Assoc. Prof., SEECS, National University of Sciences and Technology (NUST), Pakistan,tahiraa.lashari@gmail.com

\section{Sana Anwar Lashari}

Dr., School of Applied Psychology, Social Work and Policy, Universiti Utara Malaysia, Malaysia, sanalasharisana@gmail.com

\section{Md Kamrul Hasan}

Assoc. Prof., English Language Institute, United International University, Bangladesh, mkamrulhasan77@gmail.com

The study aimed at identifying the association between Bandura's four hypothesized self-efficacy sources and metacognitive reading strategies by employing reading self-efficacy beliefs as a mediating variable. A correlational research design was used. A total of 188 Saudi EFL learners were selected from five public universities of Kingdom of Saudi Arabia by employing proportionate stratified random sampling. Three questionnaires including 'questionnaire for sources of reading self-efficacy', 'reading self-efficacy beliefs questionnaire', and 'survey of reading strategies' were used to collect the data. Structural equation modelling by a statistical software, i.e., PLS 3.0 was utilised in order to test the relationships among variables. Findings provided support for the proposed conceptual framework, disclosing that all the four self-efficacy sources were significantly correlated with reading self-efficacy beliefs. Also, reading selfefficacy beliefs were significantly correlated with metacognitive reading strategies. Lastly, reading self-efficacy beliefs mediated the association between self-efficacy sources and metacognitive reading strategies.

Keywords: self-efficacy sources, reading self-efficacy beliefs, metacognitive reading strategies, Saudi EFL learners, structural equation modelling

Citation: Shehzad, M. W., Anwar Lashari, T., Anwar Lashari, S., \& Hasan, Md. K. (2020). The Interplay of Self-Efficacy Sources and Reading Self-Efficacy Beliefs in Metacognitive Reading Strategies. International Journal of Instruction, 13(4), 523-544. https://doi.org/10.29333/iji.2020.13433a 


\section{INTRODUCTION}

English language learners in Saudi Arabia face a daunting set of challenges as they must not only acquire English proficiency rapidly, but also achieve the high levels of reading required to learn content and succeed academically. Recent research revealed that Saudi students' reading proficiency is extremely low as they scored 3.90 in reading skills (such as reading comprehension) in International English Language Testing Service's (2017) out of 9 bands which is considered lowest in the world. Previous researchers affirmed that the poor English reading ability could be attributed to the fact that Saudi students memorize the text and do rote learning just to pass the exam (Alkubaidi, 2014; Alrabai, 2014, 2016; Al-Seghayer, 2014). Moreover, Saudi students do not indulge in challenging reading activities as they just memorize to pass the exams,so the use of reading strategies is being neglected by them (Al-Jarf, 2007). Furthermore, the past studies that have examined the factors that influence reading comprehension were particularly conducted with second language learners (Kieffer \& Lesaux, 2008). By focusing on Saudi EFL learners in the current study, we are convinced that important lessons would be learned for other EFL learners that are facing similar problems.

Numerous researchers are adamant that aforementioned reading problems can be solved by using different reading strategies (Sari \& Abdulrahman, 2019; Seedanont \& Pookcharoen, 2019). Out of a diverse range of reading strategies, metacognitive strategies are of utmost importance that can enhance reading comprehension (Jitendra, Burgess, \& Gajria, 2011; Poole, 2011). At a very tender age of eight to ten years, metacognitive skills or strategies start developing among children and these skills keep on developing in the coming years (Veenman \& Spaans, 2005; Veenman, Wilhelm \& Beishuizen, 2004). However, in the Saudi Arabian context, firstly, the students are not given much attention regarding metacognitive reading strategies rather they are taught surface strategies for reading purposes till the end of secondary school level (Al-Jarf, 2007). Thus, it can be speculated that they are not exposed to metacognitive knowledge till the age of 18. Secondly, they are exposed to learning of English language very late, i.e., 6th grade (Al-Mansour, 2009; Gawi, 2012). Lastly, the Saudi EFL learners' exposure to English language in their daily environment or at home is limited due to the fact that Arabic is a dominant language in KSA (Alrabai, 2016). They barely get any chance of using English outside their classroom (Alrabai, 2016; Rahman \& Alhaisoni, 2013). Although they have internet facility where they can read blogs and online books, they do not take advantage of technology and mostly use Arabic (Alrabai, 2016). A survey was conducted about the reading habits of the Arabs in a publication namely, 'What Arabs Read'. The results of the survey indicated that $85 \%$ of the Saudi nationals read only one book a year (Al-Roomy, 2013). There are various researchers who claim that since the beginning of the education, the level of reading in English among Saudi students is poor. Al-Shalan (2007) claimed that there are several causes of the poor reading level among school learners, such as lack of reading at home, watching television, and playing video games for long hours. As a consequence of the aforementioned problems, when the EFL students reach the university level, generally they are quite weak in comprehending the text and ultimately face problems in reading 
the text because they apply reading strategies that are helpful in the surface reading but not very helpful in the reading of university level books (Hermida, 2009; Ismail, 2014).

From the above arguments it can be speculated that a lot of precious time, i.e., 8 to 10 years, of Saudi school students for learning or development of metacognitive skills is probably not utilized effectively. Thus, to enhance the level of English proficiency of Saudi students in all the four skills of English language, they need to attend PreparatoryYear-Programme (PYP), before they enter the university to pursue undergraduate studies (Al-Shumaimeri, 2013). This situation has compelled the researcher to conduct research on Saudi PYP university students to examine their awareness regarding metacognitive reading strategies' usage.

The previous literature indicated a significant relationship between self-efficacy sources and self-efficacy beliefs (Arslan, 2013; Butz \& Usher, 2015; Cantrell et al., 2013; Fong \& Krause, 2014; Lin, 2016; Lin \& Tsai, 2018; Phan, 2012; Phan \& Ngu, 2016; Shehzad, Alghorbany, Lashari, Lashari, \& Razzaq, 2019; Williams, 2017; Yurt, 2014; Zarei \& Naghdi, 2017). Moreover, the review of the literature has shown that there was a relationship between self-efficacy and metacognitive reading strategies (Kargar \& Zamanian, 2014; Keskin, 2014; Nosratinia, Saveiy \& Zaker, 2014; Taghinezhad, Dehbozorgi, \& Esmaili, 2015; Tavakoli \& Koosha, 2016; Tuncer \& Dogan, 2016; Uçar, 2016; Yailagh, Birgani, Boostani, \& Hajiyakhchali, 2013; Yang \& Wang, 2015; Zarei \& Gilanian, 2015). Whereas, after a rigorous literature review, it was found that there is scarcity of studies which indicate the relationship between self-efficacy sources (i.e., mastery experience, vicarious experience, verbal persuasion, and physiological state) and metacognitive reading strategies. Therefore, the current study attempts to determine the relationship between self-efficacy sources (i.e., mastery experience, vicarious experience, verbal persuasion, and physiological state) and metacognitive reading strategies used by the Saudi EFL students, by employing reading self-efficacy as a mediator.

There are several studies in which self-efficacy was used as a mediator and the findings of these studies have indicated that self-efficacy mediates the relationship among diverse range of variables (Bates \& Khasawneh, 2007; Coutinho \& Neuman, 2008; Diseth, 2011; Fast et al., 2010; Keskin, 2014; Pajares, Hartley \& Valiante, 2001; Phan \& Ngu, 2016). In the present study, 'reading self-efficacy beliefs' was employed as a mediator. The rationale of employing it as a mediator is that in the previous literature there is an extreme dearth of studies which indicate the relationship between self-efficacy sources (i.e., mastery experience, vicarious experience, verbal persuasion, and physiological state) and metacognitive reading strategies. Yet, a strong relationship is found between self-efficacy sources and reading self-efficacy and between reading self-efficacy and metacognitive reading strategies. According to Preacher, Rucker and Hayes (2007), mediation $(\mathrm{M})$ tends to occur if there is no direct relationship between independent variable $(\mathrm{X})$ and dependent variable $(\mathrm{Y})$. In other words, $\mathrm{X}$ influences $\mathrm{Y}$ only if $\mathrm{X}$ influences $M$ and as a result $M$ influences $Y$. Thus, it can be assumed that reading selfefficacy mediates the relationship between self-efficacy sources and metacognitive reading strategies as shown in Figure 1. 


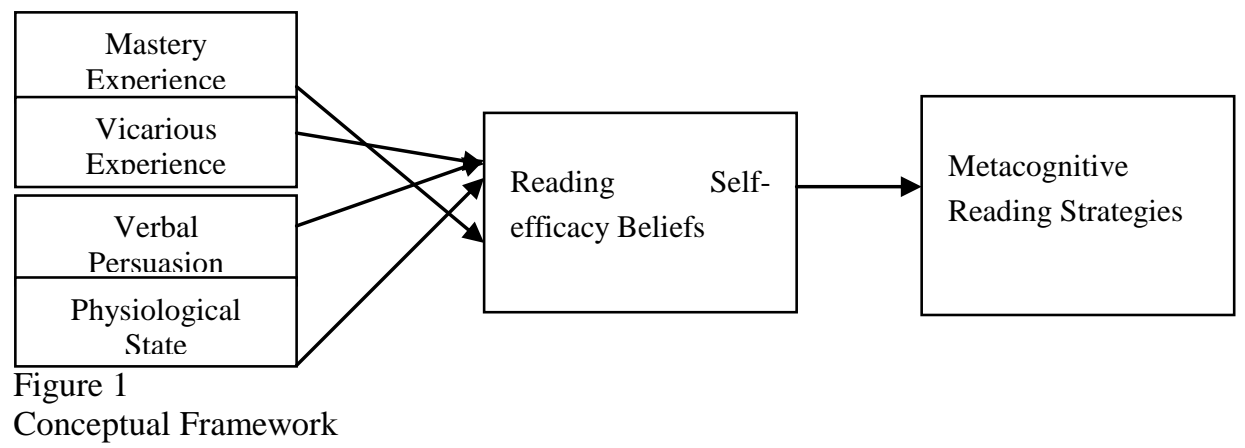

\section{Theoretical Framework}

In the social cognitive theory, Bandura $(1986,1997)$ has developed the concept of selfefficacy which denotes to the beliefs of the individual to accomplish a specific task. Bandura (1986) defined self-efficacy as "people's judgments of their capabilities to organize and execute courses of action required to attain designated types of performances" (p. 391). As the current study focused on reading thus, the variable under consideration is reading self-efficacy. Reading self-efficacy beliefs denote to learner's appraisals about their reading capabilities, i.e., how confident they are about achieving a specific reading task. Reading self-efficacy beliefs are influenced by the level of performance being achieved in the similar tasks by the readers; this contains any accompanying, response and reassurance received from the teacher (Wigfield, Guthrie, Tonks, \& Perencevich, 2004).

There are four sources by which the self-efficacy beliefs are being influenced, i.e., mastery experience, vicarious experience, verbal persuasion, and physiological/emotional state (Bandura, 1986). Mastery experience includes the past experiences being experienced by the individual regarding individual's successes and failures. This source of self-efficacy is considered as the most influential as compared to the other three sources. Self-efficacy beliefs get boosted by successes whereas, it gets lowered when one faces failures. In addition to one's personal experiences, other individuals' experiences, particularly peers' experiences become the second source of self-efficacy beliefs, i.e., vicarious experience. In other words, one can observe other successful peers and their success can persuade one to believe that one can accomplish similar task. Verbal persuasion is regarded as the third source of self-efficacy and it includes feedback from the significant people in the life of an individual, i.e., parents, peers and teachers. The feedback can influence individual's performance. Lastly, physiological/emotional state like anxiety and exhaustion can affect one's self-efficacy beliefs (Bandura, 1986).

Lastly, Metacognitive reading strategies (i.e., dependent variable) was emerged from the term metacognition in a theory named 'theory of metacognition' presented by a wellknown psychologist, John Flavell in 1979. Metacognition denotes "knowledge and cognition about cognitive phenomena" (Flavell, 1979, p. 906). 


\section{Research Objectives}

Based upon the factors identified above, the following research objectives are addressed to assess whether reading self-efficacy beliefs mediates the relationship between selfefficacy sources and metacognitive reading strategies.

1) To examine the relationship between four self-efficacy sources and reading selfefficacy beliefs among Saudi EFL students.

a. To examine the relationship between mastery experience and reading selfefficacy beliefs among Saudi EFL students.

b. To examine the relationship between vicarious experience and reading selfefficacy beliefs among Saudi EFL students.

c. To examine the relationship between verbal persuasion and reading selfefficacy beliefs among Saudi EFL students.

d. To examine the relationship between physiological state and reading selfefficacy beliefs among Saudi EFL students.

2) To determine the extent of correlation between reading self-efficacy beliefs and metacognitive reading strategies used by Saudi EFL students.

3) To determine the mediating role of reading self-efficacy beliefs between four selfefficacy sources and metacognitive reading strategies used by Saudi EFL students.

\section{METHOD}

Selection of an appropriate research method is the most critical component of a research study. Thus, it ought to be in agreement with the nature of the study (Ul-Hameed, Mohammad, \& Shahar, 2018; Ul-Hameed et al., 2019). In view of the aims of this research, the current study used a quantitative research approach and a correlational research design.

\section{Participants}

This sample of this study consisted of 188 Saudi EFL learners. All the participants of this study were male students. Data were not collected from female participants due to cultural limitations in Saudi Arabian society. The average age of the participants was 18. The sample was selected from five Saudi public universities including Al-Imam Mohammed Ibn Saud Islamic University, Shaqra University, Saudi Electronic University, King Saud University, and Qassim University. In order to select the sample, proportionate stratified random sampling was used.

\section{Instruments}

Data were collected with the help of three questionnaires. Firstly, in order to collect data regarding four self-efficacy sources, 'questionnaire for sources of reading self-efficacy' was adapted from Usher \& Pajares (2009). It comprised 18 items. More particularly, mastery experience was gauged by four items (i.e., ME1, ME2, ME3, ME4), vicarious experience was measured by six items (i.e., VE1, VE2, VE3, VE4, VE5, VE6), verbal persuasion was gauged by four items (i.e., VP1, VP2, VP3, VP4), physiological state was assessed with four items (i.e., PS1, PS2, PS3, PS4). Secondly, with the aim of collecting data regarding reading self-efficacy, 'reading self-efficacy beliefs 
questionnaire' adapted from Tobing (2013) was employed. It contained 10 items (i.e., RSEB1 to RSEB10). Lastly, in order to collect the data regarding the dependent variable of this study, i.e., metacognitive reading strategies, 'survey of reading strategies' was employed. It was adopted from Mokhtari and Sheorey (2002). It comprised 30 items (i.e., MCRS1 to MCRS 30).

\section{Procedures}

The process of data collection continued for five consecutive days. The researchers selfadministered the questionnaires in five of the aforementioned universities. Before administering the questionnaires, the participants were explicitly explained all the items present in the questionnaire. Moreover, they were guaranteed that their identity would remain confidential throughout the whole process of research. Every individual took approximately 45 minutes to fill in the three questionnaires.

\section{Data Analysis}

In order to report PLS-SEM outcomes, the present study employed two-stage approach presented by Henseler, Ringle, and Sinkovics (2009). The first stage is known as 'measurement model assessment'. The second stage is called 'structural model assessment' (Hair, Ringle, \& Sarstedt, 2013). All the steps recommended by Henseler et al. (2009) are compiled by Hameed, Basheer, Iqbal, Anwar, and Ahmad (2018) as shown in Figure 2.

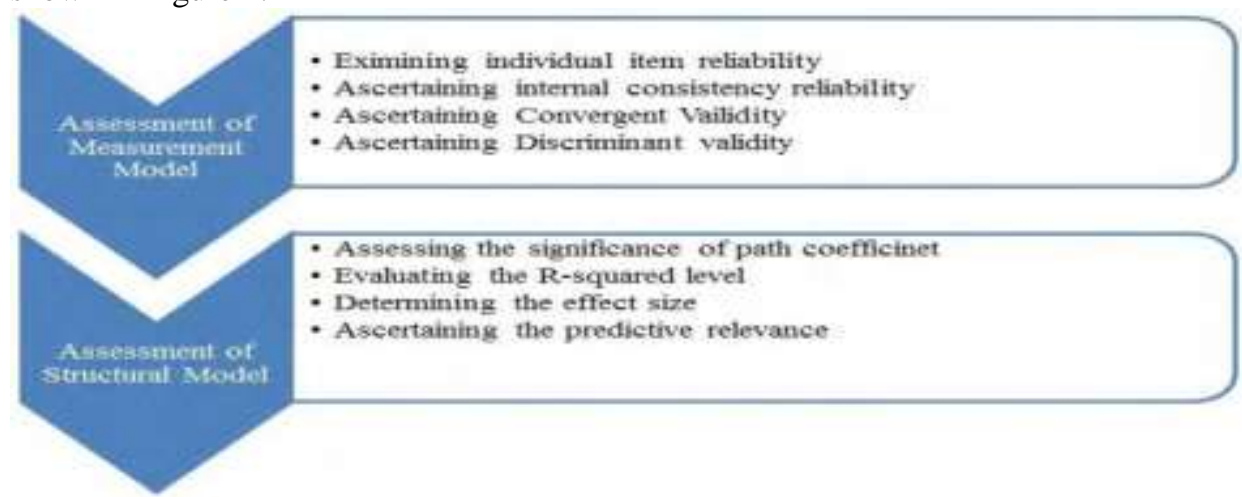

Figure 2

Two Step PLS-SEM, Source: Hameed et al. (2018)

\section{Measurement Model}

With the intention of assessing the measurement model, several entities were scrutinised including discriminant validity, average variance extracted (AVE), factor loadings, Cronbach's alpha, and composite reliability. Figure 3, Table 1 and Table 2 depict the findings of the measurement model.

Reading self-efficacy sources was gauged by 18 items. More particularly, mastery experience (ME), verbal persuasion (VP), and physiological state (PS) was gauged by four items each; however, vicarious experience (VE) was measured by six items. 
Furthermore, reading self-efficacy beliefs (RSEB) was measured by 10 items. Lastly, metacognitive reading strategies (MCRS) was measured by 30 items.

Figure 3 and Table 1 depict the factor loadings of all the variables. As stated by Hair, Black, Babin, Andersen, and Tatham (2010), factor loadings' value ought to be higher than 0.5 to establish convergent validity. In this study, the value of factor loadings of all the variables ranges from 0.70 to 0.91 . Thus, the convergent validity is established.

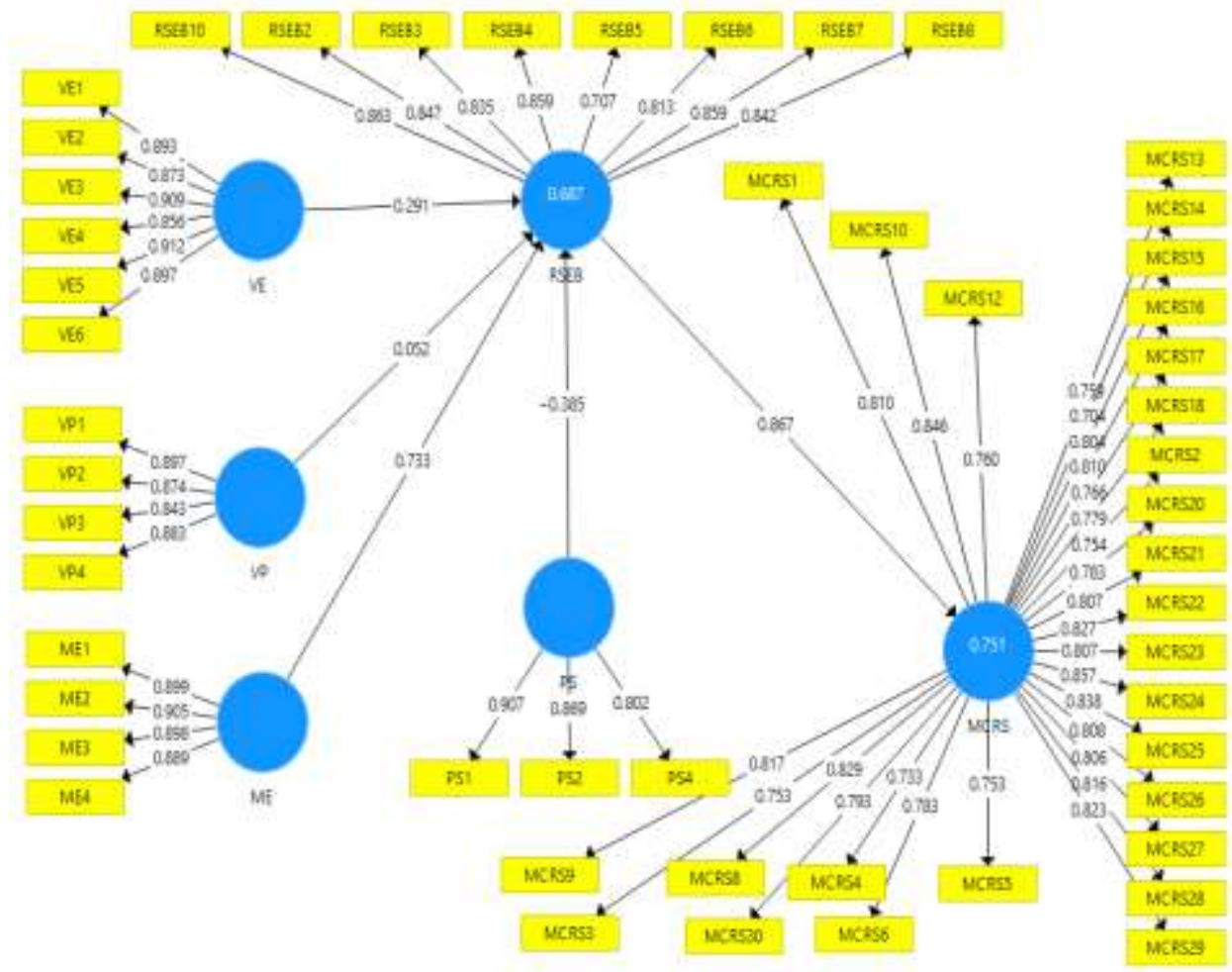

Figure 3

Measurement Model 
Table 1

Factor Loadings

\begin{tabular}{|c|c|c|c|c|c|c|}
\hline Items & MCRS & $\mathrm{ME}$ & PS & RSEB & VE & $\mathrm{VP}$ \\
\hline MCRS1 & 0.81 & & & & & \\
\hline MCRS10 & 0.846 & & & & & \\
\hline MCRS12 & 0.76 & & & & & \\
\hline MCRS13 & 0.759 & & & & & \\
\hline MCRS14 & 0.704 & & & & & \\
\hline MCRS15 & 0.804 & & & & & \\
\hline MCRS16 & 0.81 & & & & & \\
\hline MCRS17 & 0.766 & & & & & \\
\hline MCRS18 & 0.779 & & & & & \\
\hline MCRS2 & 0.754 & & & & & \\
\hline MCRS20 & 0.783 & & & & & \\
\hline MCRS21 & 0.807 & & & & & \\
\hline MCRS22 & 0.827 & & & & & \\
\hline MCRS23 & 0.807 & & & & & \\
\hline MCRS24 & 0.857 & & & & & \\
\hline MCRS25 & 0.838 & & & & & \\
\hline MCRS26 & 0.808 & & & & & \\
\hline MCRS27 & 0.806 & & & & & \\
\hline MCRS28 & 0.816 & & & & & \\
\hline MCRS29 & 0.823 & & & & & \\
\hline MCRS3 & 0.753 & & & & & \\
\hline MCRS30 & 0.793 & & & & & \\
\hline MCRS4 & 0.733 & & & & & \\
\hline MCRS5 & 0.753 & & & & & \\
\hline MCRS6 & 0.783 & & & & & \\
\hline MCRS8 & 0.829 & & & & & \\
\hline MCRS9 & 0.817 & & & & & \\
\hline ME1 & & 0.899 & & & & \\
\hline ME2 & & 0.905 & & & & \\
\hline ME3 & & 0.898 & & & & \\
\hline ME4 & & 0.889 & & & & \\
\hline PS1 & & & 0.907 & & & \\
\hline PS2 & & & 0.869 & & & \\
\hline PS4 & & & 0.802 & & & \\
\hline RSEB10 & & & & 0.863 & & \\
\hline RSEB2 & & & & 0.847 & & \\
\hline RSEB3 & & & & 0.835 & & \\
\hline RSEB4 & & & & 0.859 & & \\
\hline RSEB5 & & & & 0.707 & & \\
\hline RSEB6 & & & & 0.813 & & \\
\hline RSEB7 & & & & 0.859 & & \\
\hline RSEB8 & & & & 0.842 & & \\
\hline VE1 & & & & & 0.893 & \\
\hline VE2 & & & & & 0.873 & \\
\hline VE3 & & & & & 0.909 & \\
\hline VE4 & & & & & 0.856 & \\
\hline VE5 & & & & & 0.912 & \\
\hline VE6 & & & & & 0.897 & \\
\hline VP1 & & & & & & 0.897 \\
\hline VP2 & & & & & & 0.874 \\
\hline VP3 & & & & & & 0.843 \\
\hline VP4 & & & & & & 0.883 \\
\hline
\end{tabular}

Source: Author's own estimates based on survey data

Table 2 indicates the values of AVE, Cronbach's alpha, and composite reliability. The Cronbach's alpha value ought to be greater than 0.7 (George \& Mallery, 2001). In this study, the value of Cronbach's alpha lie between 0.82 and 0.97 . Furthermore, composite 
reliability's (CR) value ought to be equal to or higher than 0.7 and the value of AVE ought to be equal to or greater than 0.5 (Fornell \& Larcker, 1981). In this study, the values of both CR and AVE are above the aforementioned benchmarks. In addition, Table 3 displays the values of discriminant validity gathered via Heterotrait-Monotrait Ratio (HTMT) method.

Table 2

Cronbach's alpha, Composite Reliability and AVE

\begin{tabular}{llllc}
\hline Variables & Cronbach's Alpha & rho_A & CR & AVE) \\
\hline MCRS & 0.97 & 0.97 & 0.97 & 0.63 \\
ME & 0.92 & 0.92 & 0.94 & 0.80 \\
PS & 0.82 & 0.83 & 0.89 & 0.70 \\
RSEB & 0.90 & 0.93 & 0.92 & 0.63 \\
VE & 0.94 & 0.94 & 0.95 & 0.79 \\
VP & 0.89 & 0.90 & 0.92 & 0.76 \\
\hline
\end{tabular}

Table 3

Heterotrait-Monotrait Ratio (HTMT)

\begin{tabular}{lllllll}
\hline & MCRS & ME & PS & RSEB & VE & VP \\
\hline MCRS & 0.79 & & & & & \\
ME & 0.72 & 0.89 & & & & \\
PS & 0.74 & 0.86 & 0.86 & & & \\
RSEB & 0.76 & 0.77 & 0.80 & 0.79 & & \\
VE & 0.75 & 0.71 & 0.78 & 0.80 & 0.89 & \\
VP & 0.76 & 0.88 & 0.78 & 0.77 & 0.72 & 0.87 \\
\hline
\end{tabular}

\section{Structural Model}

Structural model was gauged to establish the direct impact of ME, VE, VP, and PS on RSEB. It further established the impact of RSEB on MCRS. Moreover, the assessment of indirect effect of independent variables on the dependent variable was done via mediation analysis. In order to test the relationships, path coefficients and t-value were taken into consideration. In addition, $\mathrm{R}$-Square $\left(\mathrm{R}^{2}\right)$ and predictive relevance $\left(\mathrm{Q}^{2}\right)$ were also assessed. The present study contains five direct relationships as depicted in Figure 4 and summarised in Table 4. Moreover, it contains four indirect relationships as shown in Table 5. All the nine relationships were significant considering that the t-value was higher than 1.96. In other words, reading self-efficacy sources were significantly correlated with reading self-efficacy beliefs. Moreover, reading self-efficacy beliefs were significantly correlated with metacognitive reading strategies. Lastly, reading selfefficacy beliefs successfully mediated the relationship between self-efficacy sources and metacognitive reading strategies.

Regarding effect size, Table 4 indicates the values of the effect size $\left(f^{2}\right)$. Cohen (1988) confirmed that the effect size value of 0.02 is small, 0.15 is medium, and 0.35 is strong. In this study, the value of $\mathrm{f}^{2}$ for ME was strong and for PS was small. However, $\mathrm{f}^{2}$ value for majority of the variables (i.e., VE, VP, and RSEB) was medium. 


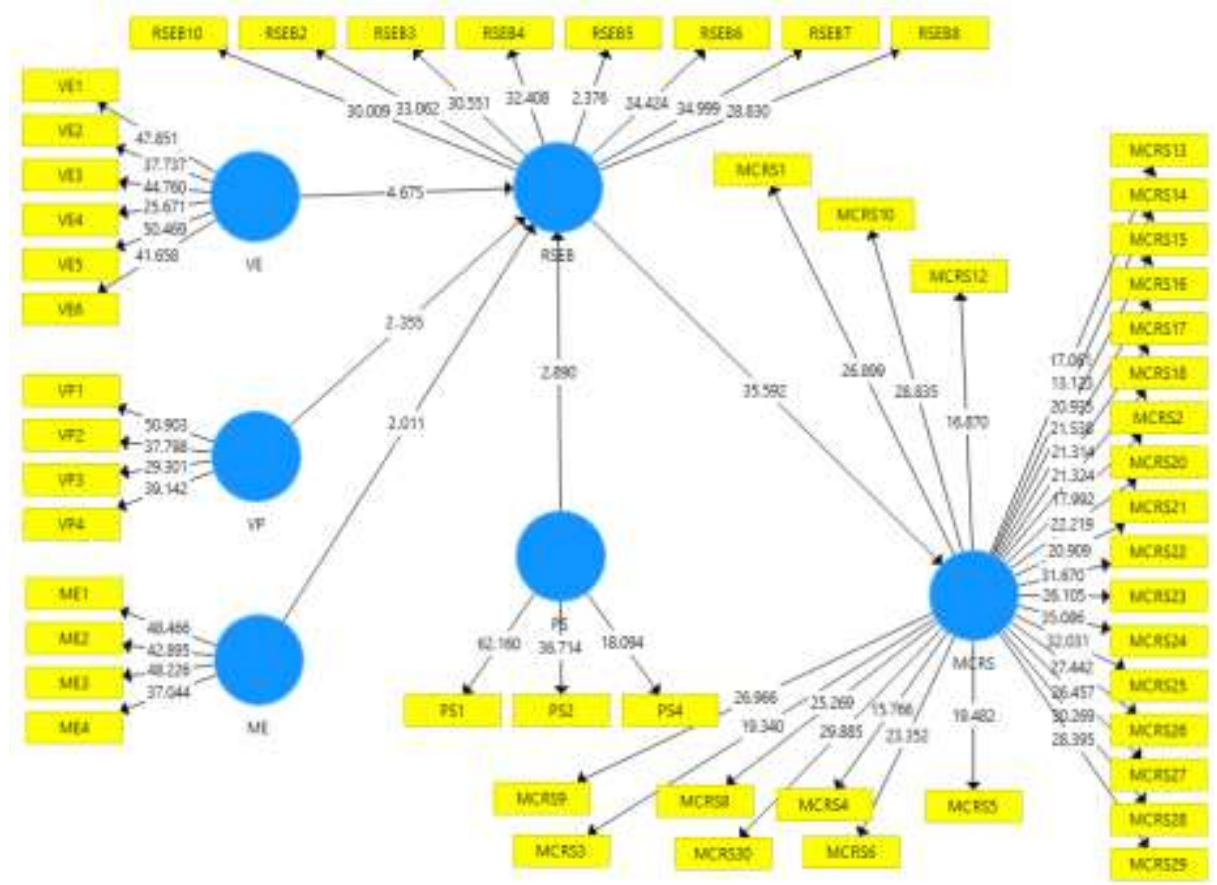

Figure 4

Structural Model Assessment

Table 4

Results of Relationships Testing (Direct Relationships)

\begin{tabular}{lllllll}
\hline & $\begin{array}{l}\text { Original } \\
\text { Sample } \\
(\mathrm{O})\end{array}$ & $\begin{array}{l}\text { Sample } \\
\text { Mean }(\mathrm{M})\end{array}$ & $\begin{array}{l}\text { Standard } \\
\text { Deviation } \\
(\text { STDEV })\end{array}$ & $\begin{array}{l}\mathrm{T} \\
(|\mathrm{O} / \mathrm{STDEV}|)\end{array}$ & $\begin{array}{c}\text { Statistics } \\
\text { P Values }\end{array}$ & $\mathrm{f}^{2}$ \\
\hline ME -> RSEB & 0.733 & 0.736 & 0.359 & 2.011 & 0.041 & 0.789 \\
PS -> RSEB & -0.385 & -0.386 & 0.133 & 2.89 & 0.004 & 0.023 \\
RSEB-> MCRS & 0.867 & 0.871 & 0.024 & 35.592 & 0 & 0.165 \\
VE -> RSEB & 0.291 & 0.303 & 0.063 & 4.675 & 0 & 0.154 \\
VP -> RSEB & 0.052 & 0.058 & 0.022 & 2.355 & 0.032 & 0.189 \\
\hline
\end{tabular}

Table 5

Results of Relationships Testing (Indirect Relationships)

\begin{tabular}{llllll}
\hline & $\begin{array}{l}\text { Original } \\
\text { Sample (O) }\end{array}$ & $\begin{array}{l}\text { Sample } \\
\text { Mean }(M)\end{array}$ & $\begin{array}{l}\text { Standard Deviation } \\
(\text { STDEV) }\end{array}$ & $\begin{array}{l}\text { T Statistics } \\
(|\mathrm{O} / \mathrm{STDEV}|)\end{array}$ & P Values \\
\hline ME -> RSEB -> MCRS & 0.116 & 0.104 & 0.065 & 2.29 & 0.033 \\
PS -> RSEB -> MCRS & 0.334 & -0.337 & 0.119 & 2.802 & 0.005 \\
VE -> RSEB -> MCRS & 0.253 & 0.263 & 0.06 & 4.198 & 0 \\
VP -> RSEB -> MCRS & 0.045 & 0.051 & 0.02 & 2.238 & 0.034 \\
\hline
\end{tabular}

Table 6 indicates the $\mathrm{R}^{2}$ values. It indicates that all the four reading self-efficacy sources (i.e., ME, VE, VP, PS) influenced reading self-efficacy beliefs (RSEB) by $68 \%$. Moreover, ME, VE, VP, PS, and RSEB influenced metacognitive reading strategies by $75 \%$. 
Table 6

Coefficient of Determination $\left(\mathrm{R}^{2}\right)$

\begin{tabular}{ll}
\hline Dependent variables & R Square \\
\hline RSEB & 0.68 \\
MCRS & 0.75 \\
\hline
\end{tabular}

Table 7 shows the values of predictive relevance $\left(Q^{2}\right)$. Henseler et al. (2009) affirmed that $\mathrm{Q}^{2}$ value ought to be greater than zero. In the current study, $\mathrm{Q}^{2}$ value for MCRS and RSEB were 0.43 and 0.39 respectively.

Table 7

Predictive Relevance $\left(\mathrm{Q}^{2}\right)$

\begin{tabular}{llll}
\hline Dependent Variables & SSO & SSE & $\mathrm{Q}^{2}(=1-\mathrm{SSE} / \mathrm{SSO})$ \\
\hline MCRS & $5,049.00$ & $2,868.75$ & 0.43 \\
RSEB & $1,496.00$ & 901.076 & 0.39 \\
\hline
\end{tabular}

\section{FINDINGS}

The study intended to determine the association between the four self-efficacy sources (i.e., ME, VE, VP, PS) and reading self-efficacy beliefs (RSEB). Moreover, it intended to determine the relationship between RSEB and metacognitive reading strategies (MCRS). Lastly, it aimed to determine the mediating role of RSEB between four selfefficacy sources and MCRS. The findings of the current study indicated a significant association between all the four self-efficacy sources and reading self-efficacy beliefs. More particularly, mastery experience (ME) was positively and significantly correlated with $\operatorname{RSEB}(\beta$-value $=0.73$; $\mathrm{t}$-value $=2.01)$. Moreover, vicarious experience showed a positive and significant association with $\operatorname{RSEB}(\beta$-value $=0.29 ; \mathrm{t}$-value $=4.67)$. In addition, verbal persuasion was significantly and positively correlated with RSEB ( $\beta$ value $=0.05 ; \mathrm{t}$-value $=2.35)$. Lastly, physiological state was significantly but negatively correlated with $\operatorname{RSEB}(\beta$-value $=-0.38 ; \mathrm{t}$-value $=2.89)$. The results also indicated positive and significant association between RSEB and MCRS $(\beta$-value $=0.86$; $t$-value $=$ 35.59).

Regarding indirect relationships, it was found that RSEB mediated the association between all of the four self-efficacy sources and MCRS. More specifically, RSEB mediated the relationship between ME and MCRS $(\beta$-value $=0.11 ; \mathrm{t}$-value $=2.29)$. In addition, RSEB acted as a mediating variable between VE and MCRS ( $\beta$-value $=0.25$; $\mathrm{t}$ value $=4.19)$. Furthermore, RSEB mediated the association between VP and MCRS ( $\beta$ value $=0.04 ; \mathrm{t}$-value $=2.23)$. Lastly, $\mathrm{RSEB}$ mediated the relationship between PS and $\operatorname{MCRS}(\beta$-value $=-0.33 ; \mathrm{t}$-value $=2.80)$.

\section{DISCUSSION}

The findings of the first research objective indicated that three out of four reading selfefficacy sources, i.e., 'mastery experience', 'vicarious experience', and 'verbal persuasion' were positively and significantly correlated with 'reading self-efficacy beliefs'. However, 'physiological state' was negatively and significantly correlated with 'reading self-efficacy beliefs'. As stated above, 'mastery experience' was significantly 
correlated with 'reading self-efficacy beliefs' $(\beta=0.73 ; \mathrm{t}=2.01)$. Also, the direction of the relationship was found to be positive. In simple words, the findings indicated that previous reading experiences of the Saudi EFL learners boosted their reading selfefficacy beliefs. Cantrell et al. (2013) affirmed that individuals who encountered positive successful experiences in the past have a higher level of self-efficacy as compared to those who encountered negative and unsuccessful experiences. The effect of mastery experience on performance was also explained by 'social cognitive theory' (Bandura, 1986). It affirmed that learners generate self-efficacy beliefs from their past experiences. The past experiences could be positive as well as negative. Positive mastery experiences (achievements) boost self-efficacy, whereas, negative mastery experiences (failures) lower self-efficacy beliefs among learners. Consequently, Bandura (1986) asserted that self-efficacy in turn affects the performance of the individuals. Thus, the current study's findings could be attributed to the possibility that Saudi EFL students might have experienced positive mastery experience related to reading, which were responsible for increasing their reading self-efficacy beliefs. This finding is in line with several studies (Arslan, 2013; Britner and Pajares, 2006; Chen \& Usher, 2013; Joët, Usher, \& Bressoux, 2011; Kaya \& Bozdag, 2016; Kiran \& Sungur, 2012; Kudo \& Mori, 2015; Lin, 2016; Lin \& Tsai, 2018; Phan, 2012; Phan \& Ngu, 2016; Tschannen-Moran \& McMaster, 2009; Usher and Pajares, 2009). The aforementioned speculation requires further approval from future studies.

Similarly, 'vicarious experience' was significantly correlated with 'reading self-efficacy beliefs' ( $\beta=0.29 ; \mathrm{t}=4.67)$. Furthermore, the relationship was positive. In other words, the findings indicated that whenever Saudi EFL learners observed their peers or other models performing well in reading, their reading self-efficacy beliefs increased. This finding is in line with other studies (Arslan, 2013; Britner \& Pajares, 2006; Chen \& Usher, 2013; Hampton \& Mason, 2003; Kaya \& Bozdag, 2016; Lin, 2016; Lin \& Tsai, 2018; Phan \& Ngu, 2016; Tschannen-Moran \& McMaster, 2009; Usher \& Pajares, 2009). 'Social cognitive theory' also affirmed that one can observe other successful peers/role models and their success can persuade one to believe that one can accomplish similar task (Bandura, 1986). However, regarding models in a learning environment, greater self-efficacy can be achieved by the learners in completing a specific academic task by observing more relevant models, i.e., peers instead of unrealistic models, i.e., teachers. As the level of skills of the teachers is far higher as compared to the skills' level of the learners, the learners are convinced in doing the similar task again when they observe their peers who are on the same level in terms of skills as compared to observing the teachers of different skills level. In addition to the skills, related characteristics (age, sex and ethnic background) of the peer models can be influential factors. Therefore, the models that are more related to the learners can have a higher influence on the self-efficacy beliefs and performance of the learners (Schunk \& Hanson, 1985; Schunk, 1987). In the current study, the sample consisted of Saudi EFL learners. All of them were in the same class and shared similar educational level and nationality. Thus, it can be speculated that when they observed positive models in their class, in turn, their reading self-efficacy was elevated. Their teachers also encouraged loud reading in classes in the PYP. This activity provided the EFL learners with the 
opportunity of observing others' loud reading skills. As a consequence, this might have positively affected their reading self-efficacy. This conjecture needs further validation from future researchers.

Moreover, 'verbal persuasion' was positively and significantly correlated with 'reading self-efficacy beliefs' $(\beta=0.05 ; \mathrm{t}=2.35)$. This finding is consistent with numerous past studies (Arslan, 2013; Britner \& Pajares, 2006; Chen \& Usher, 2013; Hampton \& Mason, 2003; Joët et al., 2011; Kaya \& Bozdag, 2016; Kiran \& Sungur, 2012; Lin, 2016; Lin \& Tsai, 2018; Phan, 2012; Phan \& Ngu, 2016; Tschannen-Moran \& McMaster, 2009; Usher \& Pajares, 2009). In simpler terms, the finding indicated that Saudi EFL learners' reading self-efficacy increases upon receiving feedback from teachers and other people. The possible speculation for a positive relationship between 'verbal persuasion' and 'reading self-efficacy' could be authentic appreciation from teachers or other important people in the life of Saudi EFL learners. Ur (1996), a wellknown EFL teacher, affirmed that authentic and convincing applause can be beneficial to the learners and vice versa. Thus, in view of the above discussion, it can be speculated that the Saudi EFL learners might have received authentic appreciation from their teachers, which in turn increased their reading self-efficacy. However, this speculation needs further confirmation from future studies.

In addition, 'physiological state' showed a significant but negative association with reading self-efficacy beliefs. To put this finding in other words, higher anxiety among Saudi EFL learners decreases their reading self-efficacy beliefs and vice versa. This finding is consistent with numerous past studies (Kaya \& Bozdag, 2016; Lin \& Tsai, 2018; Phan, 2012). Furthermore, social cognitive theory affirmed that higher level of anxiety is responsible for lower level of self-efficacy beliefs among students (Bandura, 1986).

The results of the second research objective indicated that reading self-efficacy beliefs are positively and significantly correlated with metacognitive reading strategies ( $\beta$ value $=0.86$; $\mathrm{t}$-value $=35.59)$. To put it in other words, higher self-efficacy beliefs among Saudi EFL learners increased the frequency of usage of metacognitive reading strategies. These findings are in line with several past studies (Ahmadian \& Pasand, 2017; Kargar \& Zamanian, 2014; Keskin, 2014; Li \& Wang, 2010; Naseri \& Zaferanieh, 2012; Shang, 2010; Zare \& Mobarakeh, 2011). According to Sheorey and Mokhtari (2001), "skilled readers . . . are more able to reflect on and monitor their cognitive processes while reading. They are aware not only of which strategies to use, but they also tend to be better at regulating the use of such strategies while reading" ( $p$. 445). Self-efficacy beliefs play a substantial role in learners' selection of activities. To put it in another way, learners feel hesitant doing activities which they think are beyond their abilities and merely embark on those tasks or activities which they believe are within the reach of their abilities (Bandura, 1986). In addition, in Magogwe and Oliver's (2007) study, self-efficacy beliefs and metacognitive strategies were highly correlated with each other as compared to the relationship of other strategies with self-efficacy beliefs. This may happen due to the reason that high self-efficacious learners are more autonomous and metacognitive strategies best harmonise with this characteristic. 
The speculation of the current study's findings can be attributed to the fact that Saudi EFL learners were highly self-efficacious in reading and thus were perhaps more enthused. Due to this enthusiasm and motivation, they might have put more effort in the usage of the metacognitive reading strategies. Their more frequent usage of metacognitive reading strategies denotes that they were liable to be more involved (Linnenbrink \& Pintrich, 2003) and more self-controlled in learning tasks (Zimmerman, 2000). The finding also delineates the substantial role of 'reading self-efficacy beliefs' in a way that readers approach their reading tasks. Furthermore, it authenticates Bandura's $(1977,1986)$ theory that self-efficacy impacts the behaviours of the learners by means of influencing the way they reflect, self-motivate, and endure while facing challenging tasks. However, the above-mentioned speculations need further investigation.

Lastly, the findings of the third research objective directed that reading self-efficacy beliefs successfully mediated the relationship between self-efficacy sources and metacognitive reading strategies. The current finding is supported by social cognitive theory which confirmed that self-efficacy beliefs are originated from four self-efficacy sources and in turn, self-efficacy beliefs influence the performance of the individuals (Bandura, 1986, 1997). It is worth mentioning here that the main reason of employing 'reading self-efficacy beliefs' (RSEB) as a mediator is that the researcher wanted to examine the relationship between four 'self-efficacy sources' (SES) and 'metacognitive reading strategies' (MCRC). It was not possible to determine the relationship between SES and MCRS directly because there was lack of past research studies conducted on these two variables. According to Preacher et al., (2007), mediation (M) occurs only if there is no direct relationship between independent variable $(\mathrm{X})$ and dependent variable ( $\mathrm{Y})$. In other words, if $\mathrm{M}$ is influenced by $\mathrm{X}$, and $\mathrm{Y}$ is influenced by $\mathrm{M}$, then in turn, $\mathrm{Y}$ is indirectly influenced by $\mathrm{X}$. Thus, the only way to determine the relationship between SES and MCRS was to introduce a mediating variable between two variables. The researcher employed RSEB as a mediator due to the reason that there is enough evidence in the literature which showed a significant relationship between SES and selfefficacy beliefs (Arslan, 2013; Chen \& Usher, 2013; Joët et al., 2011; Kaya \& Bozdag, 2016; Kudo \& Mori, 2015; Lin, 2016; Lin \& Tsai, 2018; Phan, 2012; Phan \& Ngu, 2016). Also, there are plentiful studies that showed a significant association between RSEB and MCRS (Ahmadian \& Pasand, 2017; Kargar \& Zamanian, 2014; Keskin, 2014; Li \& Wang, 2010; Naseri \& Zaferanieh, 2012; Shang, 2010; Zare \& Mobarakeh, 2011).

Thus, the findings of the current study made a theoretical contribution by determining the relationship between SES and RC by employing SEB as a mediating variable. More specifically, the current study is the first of its nature which examined the relationship between 'self-efficacy sources' and 'metacognitive reading strategies'. Earlier than this, several researchers examined the relationship between self-efficacy sources and a diverse range of variables including language proficiency, writing achievement, mathematics achievement, science achievement, academic achievement etc. (e.g., Hampton \& Mason, 2003; Joët et al., 2011; Pajares, Johnson, \& Usher, 2007; Phan, 2012). However, little attention was given to research regarding the relationship 
between 'self-efficacy sources' and 'metacognitive reading strategies'. The review of literature clearly shows that there was a need to conduct a study on the relationship of self-efficacy sources and metacognitive reading strategies. Therefore, the current study filled this literature gap.

\section{CONCLUSION}

In a nutshell, current study's findings indicated that all the four self-efficacy sources played a substantial role in boosting the reading self-efficacy of the Saudi EFL learners, which consequently increased their metacognitive reading strategies' usage. More particularly, out of four self-efficacy sources, mastery experience showed a stronger relationship with reading self-efficacy beliefs as compared to other sources. In other words, students' reading self-efficacy gets boosted majorly by remembering their successful past experiences regarding reading. Moreover, another major finding is that unlike other sources, physiological state showed a negative and significant relationship with reading self-efficacy beliefs. In simple terms, aforementioned finding indicates that Saudi EFL learners' reading self-efficacy beliefs decrease with the increase in anxiety and vice versa. These findings have several implications for EFL learners, instructors and educational policymakers.

\section{LIMITATIONS AND FUTURE RESEARCH}

The current study has several limitations such as the data was gathered from male Saudi EFL students and university students therefore the study results cannot be generalised to whole Saudi student population. Thus, future researchers should consider collecting data from female learners as well as from schools to compare differences in English learning in gender and age using same study variables. Moreover, the current study was quantitative which limit our understanding. Therefore, future studies may adopt qualitative or mixed-methods research design to get a deeper perspective of the phenomena.

\section{REFERENCES}

Ahmadian, M., \& Pasand, P. G. (2017). EFL learners' use of online metacognitive reading strategies and its relation to their self-efficacy in reading. The Reading Matrix: An International Online Journal, 17(2), 117-132.

Al-Jarf, R. (2007). Developing reading and literacy in Saudi Arabia. Riyadh: King Saud University. ERIC Document No. ED497944. Retrieved from http://files.eric.ed.gov/fulltext /ED497944.pdf.

Alkubaidi, M. A. (2014). The relationship between Saudi English major university students' writing performance and their learning style and strategy use. English Language Teaching, 7(4), 83-95.

Al-Mansour, N. (2009). Bilingualism and the need for early EFL education in the Kingdom of Saudi Arabia. J. King Saud University, 21(1), 1-12. 
Alrabai, F. (2014). Motivational practices in English as a foreign language classes in Saudi Arabia: Teachers beliefs and learners perceptions. Arab World English Journal, 5(1), 224-246.

Alrabai, F. (2016). Factors underlying low achievement of Saudi EFL learners. International Journal of English Linguistics, 6(3), 21-37.

Al-Roomy, M. (2013). An action research study of collaborative strategic reading in English with Saudi medical students (Unpublished doctoral dissertation). University of Sussex, Sussex, United Kingdom.

Al-Seghayer, K. (2014). The four most common constraints affecting English teaching in Saudi Arabia. International Journal of English Linguistics, 4(5), 17-26.

Alshalan, R. (2007). Reading: Practical ways to encourage children to like reading. Riyadh: Dar-Almgren.

Al-Shumaimeri, Y. (2013). The effect of an intensive English language program on first year university students' motivation. J of Edu \& Psychological Sciences, 14(1), 11-32.

Arslan, A. (2013). Investigation of relationship between sources of self-efficacy beliefs of secondary school students and some variables. Educational Sciences: Theory and Practice, 13(4), 1983-1993.

Bandura, A. (1977). Self-efficacy: Toward a unifying theory of behavioral change. Psychological Review, 84(2), 191-215.

Bandura, A. (1986). The explanatory and predictive scope of self-efficacy theory. Journal of Social and Clinical Psychology, 4(3), 359-373.

Bandura, A. (1997). Self-efficacy: The exercise of control. New York, NY: Freeman.

Bates, R., \& Khasawneh, S. (2007). Self-efficacy and college students' perceptions and use of online learning systems. Computers in Human Behavior, 23(1), 175-191.

Britner, S. L., \& Pajares, F. (2006). Sources of science self-efficacy beliefs of middle school students. Journal of Research in Science Teaching, 43(5), 485-499.

Butz, A. R., \& Usher, E. L. (2015). Salient sources of early adolescents' self-efficacy in two domains. Contemporary Educational Psychology, 42(1), 49-61.

Cantrell, S. C., Correll, P., Clouse, J., Creech, K., Bridges, S., \& Owens, D. (2013).

Patterns of self-efficacy among college students in developmental reading. Journal of College Reading and Learning, 44(1), 8-34.

Chen, J. A., \& Usher, E. L. (2013). Profiles of the sources of science selfefficacy. Learning and Individual Differences, 24(1), 11-21.

Cohen, J. (1988). Statistical power analysis for the behavioral sciences. Hillsdale, NJ: Erlbaum. 
Coutinho, S. A., \& Neuman, G. (2008). A model of metacognition, achievement goal orientation, learning style and self-efficacy. Learning Environ. Res, 11(2), 131-151.

Usher, E. L., \& Pajares, F. (2009). Sources of self-efficacy in mathematics: A validation study. Contemporary Educational Psychology, 34(1), 89-101.

Diseth, Å. (2011). Self-efficacy, goal orientations and learning strategies as mediators between preceding and subsequent academic achievement. Learning and Individual Differences, 21(2), 191-195.

Elyas, T., \& Picard, M. (2010). Saudi Arabian educational history: Impacts on English language teaching. Education, Business and Society: Contemporary Middle Eastern Issues, 3(2), 136-145.

Fareh, S. (2010). Challenges of teaching English in the Arab world: Why can't EFL programs deliver as expected? Pro-Soc. and Behavioral Sciences, 2(2), 3600-3604.

Fast, L. A., Lewis, J. L., Bryant, M. J., Bocian, K. A., Cardullo, R. A., Rettig, M., \& Hammond, K. A. (2010). Does math self-efficacy mediate the effect of the perceived classroom environment on standardized math test performance? Journal of Educational Psychology, 102(3), 729.

Flavell, J. H. (1979). Metacognition and cognitive monitoring: A new area of cognitivedevelopmental inquiry. American Psychologist, 34(10), 906-911.

Fong, C. J., \& Krause, J. M. (2014). Lost confidence and potential: a mixed methods study of underachieving college students' sources of self-efficacy. Social Psychology of Education, 17(2), 249-268. doi: 10.1007/s11218-013-9239-1.

Fornell, C., \& Larcker, D. F. (1981). Evaluating structural equation models with unobservable variables and measurement error. $J$ of Marketing Research, 18(1), 39-50.

Gawi, E. M. K. (2012). The effects of age factor on learning English: A case study of learning English in Saudi schools, Saudi Arabia. English Lang Teaching, 5(1), 127-139.

George, D., \& Mallery, P. (2001). SPSS for Windows. Needham Heights, MA: Allyn \& Bacon.

Hair Jr., J. F., Black, W. C., Babin, B. J., Andersen, R. E., \& Tatham, R. L. (2010). Mutilvariate data analysis. Upper Saddle River, NJ: Pearson Prentice Hall.

Hair Jr., J. F., Ringle, C. M., \& Sarstedt, M. (2013). Editorial-partial least squares structural equation modeling: Rigorous applications, better results and higher acceptance. Long Range Planning, 46(1-2), 1-12.

Hameed, W. U., Basheer, M. F., Iqbal, J., Anwar, A., \& Ahmad, H. K. (2018). Determinants of Firm's open innovation performance and the role of R \& D department: an empirical evidence from Malaysian SME's. Journal of Global Entrepreneurship Research, 8(1), 29-42. doi: 10.1186/s40497-018-0112-8. 
Hampton, N. Z., \& Mason, E. (2003). Learning disabilities, gender, sources of efficacy, self-efficacy beliefs, and academic achievement in high school students. Journal of School Psychology, 41(2), 101-112.

Henseler, J., Ringle, C. M., \& Sinkovics, R. R. (2009). The use of partial least squares path modeling in international marketing. In R. R. Sinkovics, \& P. N. Ghauri (Eds.), New challenges to international marketing, Volume 20 (pp. 277-319). Emerald.

Hermida, D. (2009). The importance of teaching academic reading skills in first-year university courses. The International Journal of Research and Review, 3(1), 20-30.

IELTS Partners (British Council, IDP: IELTS Australia Pty Ltd., and Cambridge English Language Assessment). (2017). IELTS Researchers: Test Taker Performance 2017. Retrieved from https://www.ielts.org/teaching-and-research/test-takerperformance_2017.aspx.

Ismail, N. M. (2014). Effectiveness of a metacognitive reading strategies program for improving low achieving EFL readers. International Education Studies, 8(1), 71-81.

Jacobs, J. E., \& Paris, S. G. (1987). Children's metacognition about reading: Issues in definition, measurement, and instruction. Educational Psychologist, 22(3-4), 255-278.

Jitendra, A. K., Burgess, C., \& Gajria, M. (2011). Cognitive strategy instruction for improving expository text comprehension of students with learning disabilities. The quality of evidence. Exceptional Children, 77(2), 135-159.

Joët, G., Usher, E. L., \& Bressoux, P. (2011). Sources of self-efficacy: An investigation of elementary school students in France. J of Educational Psychology, 103(3), 649-663.

Kargar, M., \& Zamanian, M. (2014). The relationship between self-efficacy and reading comprehension strategies used by Iranian male and female EFL learners. International Journal of Language Learning and Applied Linguistics World, 7(2), 313-325.

Kaya, D., \& Bozdag, H. C. (2016). Resources of mathematics self-efficacy and perception of science self-efficacy as predictors of academic achievement. European Journal of Contemporary Education, 18(4), 438-451. doi: 10.13187/ejced.2016.18.438.

Keskin, H. K. (2014). A path analysis of metacognitive strategies in reading, selfefficacy and task value. Int Journal of Social Science and Education, 4(4), 798-808.

Kieffer, M. J., \& Lesaux, N. K. (2008). The role of derivational morphology in the reading comprehension of Spanish-speaking English language learners. Reading and Writing, 21(8), 783-804.

Kiran, D., \& Sungur, S. (2012). Middle school students' science self-efficacy and its sources: Examination of gender difference. J of Sci Edu and Tech, 21(5), 619-630.

Kudo, H., \& Mori, K. (2015). A preliminary study of increasing self-efficacy in junior high school students: Induced success and a vicarious experience. Psychological Reports, 117(2), 631-642. 
Kummin, S., \& Rahman, S. (2010). The relationship between the use of metacognitive strategies and achievement in English. Pro - Soc and Behavioral Sci, 7(1), 145-150.

Law, Y. K. (2009). The role of attribution beliefs, motivation and strategy use in Chinese fifth-graders' reading comprehension. Educational Research, 51(1), 77-95.

Li, Y., \& Wang, C. (2010). An empirical study of reading self-efficacy and the use of reading strategies in the Chinese EFL context. Asian EFL Journal, 12(2), 144-162.

Lin, G. Y. (2016). Self-efficacy beliefs and their sources in undergraduate computing disciplines: An examination of gender and persistence. Journal of Educational Computing Research, 53(4), 540-561.

Lin, T. J., \& Tsai, C. C. (2018). Differentiating the sources of Taiwanese high school students' multidimensional science learning self-efficacy: An examination of gender differences. Research in Science Education, 48(3), 575-596.

Linnenbrink, E. A., \& Pintrich, P. R. (2003). The role of self-efficacy beliefs in student engagement and learning in the classroom. Read. \& Writing Quarterly, 19(2), 119-137.

Magogwe, J. M., \& Oliver, R. (2007). The relationship between language learning strategies, proficiency, age and self-efficacy beliefs: A study of language learners in Botswana. System, 35(3), 338-352.

Mokhtari, K., \& Sheorey, R. (2002). Measuring ESL students' awareness of reading strategies. Journal of Developmental Education, 25(3), 2-11.

Naseri, M., \& Zaferanieh, E. (2012). The relationship between reading self-efficacy beliefs, reading strategy use and reading comprehension level of Iranian EFL learners. World Journal of Education, 2(2), 64-75.

Nosratinia, M., Saveiy, M., \& Zaker, A. (2014). EFL learners' self-efficacy, metacognitive awareness, and use of language learning strategies: how are they associated? Theory and Practice in Language Studies, 4(5), 1080-1092. doi: 10.4304/tpls.4.5.1080-1092.

Pajares, F., Hartley, J., \& Valiante, G. (2001). Response format in writing self-efficacy assessment: Greater discrimination increases prediction. Measurement and Evaluation in Counseling and Development, 33(4), 214-221.

Pajares, F., Johnson, M. J., \& Usher, E. L. (2007). Sources of writing self-efficacy beliefs of elementary, middle, and high school students. Research in the Teaching of English, 42(1), 104-120.

Phan, H. P. (2012). The development of English and mathematics self-efficacy: A latent growth curve analysis. The Journal of Educational Research, 105(3), 196-209.

Phan, H. P., \& Ngu, B. H. (2016). Sources of self-efficacy in academic contexts: A longitudinal perspective. School Psychology Quarterly, 31(4), 548-564. 
Poole, A. (2011). The online reading strategies used by five successful Taiwanese ESL learners. Asian Journal of English Language Teaching, 21(1), 65-87.

Preacher, K. J., Rucker, D. D., \& Hayes, A. F. (2007). Addressing moderated mediation hypotheses: Theory, methods, and prescriptions. Multivariate Behavioral Research, 42(1), 185-227.

Rahman, M. M., \& Alhaisoni, E. (2013). Teaching English in Saudi Arabia: Prospects and challenges. Academic Research International, 4(1), 112-118.

Rajab, H. (2013). Developing speaking and writing skills of L1 Arabic EFL learners through teaching of IPA phonetic codes. Theory and Practice in Lan Stu, 3(4), 653-659.

Sari, M., \& Abdulrahman, T. R. (2019). Discovery Learning (Dl) strategy on students reading comprehension in report text. Lingua, 15(2), 19-26.

Schunk, D. H. (1987). Peer models and children's behavioral change. Review of Educational Research, 57(2), 149-174.

Schunk, D. H., \& Hanson, A. R. (1985). Peer models: Influence on children's selfefficacy and achievement. Journal of Educational Psychology, 77(3), 313-322.

Seedanont, C., \& Pookcharoen, S. (2019). Fostering metacognitive reading strategies in Thai EFL classrooms: A focus on proficiency. English Language Teach, 12(7), 75-86.

Shang, H. F. (2010). Reading strategy use, self-efficacy and EFL reading comprehension. Asian EFL Journal, 12(2), 18-42.

Shehzad, M. W., Alghorbany, A., Lashari, S. A., Lashari, T. A., \& Razzaq, S. (2019). The interplay between pronunciation self-efficacy sources and self-efficacy beliefs: A structural equation modeling approach. Indonesian J of App Linguistics, 9(1), 177-187.

Sheorey, R., \& Mokhtari, K. (2001). Differences in the metacognitive awareness of reading strategies among native and non-native readers. System, 29(1), 431-449.

Taghinezhad, A., Dehbozorgi, R., \& Esmaili, N. (2015). The influence of teaching metacognitive reading strategies on the reading self-efficacy beliefs of Iranian EFL learners: An experimental study. Modern J of Lang Teaching Methods, 5(4), 728-734.

Tavakoli, H., \& Koosha, M. (2016). The effect of explicit metacognitive strategy instruction on reading comprehension and self-efficacy beliefs: The case of Iranian University EFL students. Porta Linguarum: Revista Internacional de Didáctica de Las Lenguas Extranjeras, 25(1), 119-133.

Tobing, I. R. A. (2013). The relationship of reading strategies and self-efficacy with the reading comprehension of high school students in Indonesia (Unpublished doctoral dissertation). University of Kansas, Lawrence, United States of America.

Tschannen-Moran, M., \& McMaster, P. (2009). Sources of self-efficacy: Four professional development formats and their relationship to self-efficacy and implementation of a new teaching strategy. The Elementary School J, 110(2), 228-245. 
Tuncer, M., \& Dogan, Y. (2016). Relationships among foreign language anxiety, academic self-efficacy beliefs and metacognitive awareness: A structural equation modelling. International Journal of Learning and Development, 6(2), 31-41.

Uçar, S. B. (2016). The exploration of the relationship between self-efficacy and strategy use in a Turkish context. Current Research in Education, 2(3), 186-198.

Ul-Hameed, W., Mohammad, H., \& Shahar, H. (2018). Microfinance institute's nonfinancial services and women-empowerment: The role of vulnerability. Management Science Letters, 8(10), 1103-1116.

Ul-Hameed, W., Mohammad, H., Shahar, H., Aljumah, A., \& Azizan, S. (2019). The effect of integration between audit and leadership on supply chain performance: Evidence from UK based supply chain companies. Uncertain Supply Chain Management, 7(2), 311-328.

Ur, P. (1996). A course in language teaching: Theory and practice. Cambridge, UK: Cambridge University Press.

Usher, E. L., \& Pajares, F. (2009). Sources of self-efficacy in mathematics: A validation study. Contemporary Educational Psychology, 34(1), 89-101.

Veenman, M. V. J., \& Spaans, M. A. (2005). Relation between intellectual and metacognitive skills: Age and task differences. Learning and Individual Differences, 15(1), 159-176.

Veenman, M. V. J., Wilhelm, P., \& Beishuizen, J. J. (2004). The relation between intellectual and metacognitive skills from a developmental perspective. Learning and Instruction, 14(1), 89-109.

Webb-Williams, J. (2017). Science self-efficacy in the primary classroom: Using mixed methods to investigate sources of self-efficacy. Research in Science Education, 48(5), 1-23. doi: 10.1007/s11165-016-9592-0.

Wigfield, A., Guthrie, J. T., Tonks, S., \& Perencevich, K. C. (2004). Children's motivation for reading: Domain specificity and instructional influences. The Journal of Educational Research, 97(6), 299-310.

Yailagh, M. S., Birgani, S. A., Boostani, F., \& Hajiyakhchali, A. (2013). The relationship of self-efficacy and achievement goals with metacognition in female high school students in Iran. Procedia-Social and Behavioral Sciences, 84(1), 117-119.

Yang, P. L., \& Wang, A. L. (2015). Investigation the relationship among language learning strategies, English self-efficacy, and explicit strategy instructions. Taiwan Journal of TESOL, 12(1), 35-62.

Yurt, E. (2014). The predictive power of self-efficacy sources for mathematics achievement. Egitim ve Bilim, 39(176), 159-169. doi: 10.15390/EB.2014.3443. 
Zare, M., \& Mobarakeh, S. D. (2011). The relationship between self-efficacy and use of reading strategies: The case of Iranian senior high school students. Studies in Literature and Language, 3(3), 98-105. doi: 10.3968/j.sll.1923156320110303.148.

Zarei, A. A., \& Gilanian, M. (2015). Self-efficacy as a function of language learning strategy use. British Journal of Education, Society \& Behavioral Science, 9(3), 223-235. doi: 10.9734/BJESBS/2015/18735.

Zarei, A. A., \& Naghdi, F. (2017). Sources of self-efficacy as predictors of EFL learners' course performance. European o-J of Natural and Social Sci, 6(1), 68-80.

Zimmerman, B. J. (2000). Self-efficacy: An essential motive to learn. Contemporary Educational Psychology, 25(1), 82-91. 